\title{
LATE RESULTS OF TREATMENT OF CONGENITAL DISLOCATION OF THE HIP*
}

\author{
G. M. Muller, Ceylon, and H. J. Seddon, London, England
}

From the Institute of Orthopaedics, Royal National Orthopaedic Hospital, London

During the years 1949-50 a review was made of the results of treatment of congenital dislocation of the hip in patients dealt with at the Royal National Orthopaedic Hospital during the half-century ended in 1940. This was the era of closed reduction; the earlier cases were treated by pioneers, and at the Orthopaedic Hospital, at any rate, it was distinguished by an aversion from operative intervention. The risk of operation cannot have been a serious deterrent. There was only one post-operative death in the 100 operations of various types carried out on the children in the whole series. Thus either the powerful continental influence or private pessimism determined the prevailing conservative attitude. A number of members of the staff, in particular Laming Evans (1930), devoted immense pains to the practice of manipulative reduction; they followed their patients with great care, but there was no established machinery for securing their attendance for re-examination. Everything depended on the faithfulness of the surgeon and of patients and their parents. All notes were written by hand, and many of them were inadequate. Although the records of 889 cases were available, and every patient was invited to attend, only 264 were traced. The length of time that had elapsed since treatment, the vicissitudes of two wars (during the second all children were for a time evacuated from London), the normal movements of population, and deaths all contributed to the failure to trace over two-thirds of the patients. No more striking proof could be found of the need for a ruthlessly efficient follow-up organisation.

Our chief aim was to determine the fate of hips reduced by orthodox closed reduction, so as to furnish, if possible, a basis for assessment of the efficacy of the new regimen, namely, closed reduction as the primary means of treatment, and early operative intervention if closed reduction was not immediately successful, or if some anatomical abnormality of the reduced hip led to recurrence of the dislocation. At the same time the results of operative intervention were assessed.

\section{GENERAL FEATURES}

The sex incidence, frequency of involvement of either or both hips, and the relationship between the two are shown in Table I. This table brings out the comparability between the whole series of 889 and the 264 cases examined, as regards sex, incidence of bilateral involvement, frequency of right and left affected joints, and the combinations of sex and side. Sex-The preponderance of females over males in the ratio of eleven to two in both series is similar to that reported by other observers. Of those with dislocation of one hip only, roughly five females were affected for every male, in both series. Of those with both hips affected, seven females were affected for every male, in both series.

One or both hips-The ratio of unilateral to bilateral dislocations was about two to one in the whole series and in the examined cases. In the unilateral cases there was a three to two predominance of the left side in the whole series; in the examined cases slightly more than twice as many left hips as right were found.

In both series, whereas the dislocation was bilateral in one-quarter of the males, one-third of all the females were so affected. Seven-eighths of the bilateral cases were in females both in the whole series and in the examined cases.

* A summary of this paper was presented at the Spring Meeting of the British Orthopaedic Association, Cambridge, 1951 . 
TABLE 1

General Statistics

Sex incidence. Frequency of involvement of either or both joints

\begin{tabular}{|c|c|c|c|c|c|c|}
\hline \multirow[b]{2}{*}{ Sex } & \multicolumn{4}{|c|}{ All patients } & \multicolumn{2}{|c|}{ Patients examined } \\
\hline & $\begin{array}{l}\text { Males } \\
\text { Females } \\
\text { Total }\end{array}$ & $\begin{array}{l}140(1 \\
749(8 \\
889\end{array}$ & $\begin{array}{l}5.5 \%) \\
4.5 \%)\end{array}$ & & $\begin{array}{ll}\text { Males } & \\
\text { Females } & 2 \\
\text { Total } & 2\end{array}$ & $\begin{array}{r}42(15 \cdot 9 \%) \\
222(84 \cdot 1 \%) \\
264\end{array}$ \\
\hline One or both sides & $\begin{array}{l}\text { Bilateral } \\
\text { Unilateral } \\
\text { Total }\end{array}$ & $\begin{array}{l}279(3 \\
599(6 \\
878\end{array}$ & $\begin{array}{l}1.4 \%) \\
8.6 \% \\
-11 \text { cases }\end{array}$ & s unclassified) & \multicolumn{2}{|c|}{$\begin{array}{lr}\text { Bilateral } & 92(34 \cdot 9 \%) \\
\text { Unilateral } & 172(65 \cdot 1 \%) \\
\text { Total } & 264\end{array}$} \\
\hline $\begin{array}{l}\text { Sex incidence in } \\
\text { unilateral cases }\end{array}$ & $\begin{array}{l}\text { Males : } \\
\text { Females } \\
\qquad 3\end{array}$ & $\begin{array}{l}\text { Right } \\
41 \\
183 \\
37 \cdot 4 \%)\end{array}$ & $\begin{array}{l}\text { Left } \\
62 \\
313 \\
(62 \cdot 8 \%)\end{array}$ & $\begin{array}{l}\text { Total } \\
103(17 \cdot 2 \%) \\
496(82 \cdot 8 \%)\end{array}$ & \multicolumn{2}{|c|}{ 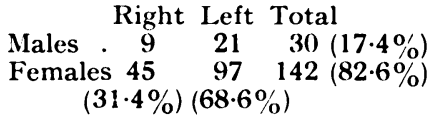 } \\
\hline $\begin{array}{l}\text { Sex incidence in } \\
\text { bilateral cases }\end{array}$ & $\begin{array}{l}\text { Males } \\
\text { Females } \\
\text { Total }\end{array}$ & $\begin{aligned} & 35 \\
244 & (1 \\
279 & (8\end{aligned}$ & $\begin{array}{l}2 \cdot 6 \%) \\
7 \cdot 4 \%)\end{array}$ & & $\begin{array}{l}\text { Males } \\
\text { Females } \\
\text { Total }\end{array}$ & $\begin{array}{l}12(13 \%) \\
80(87 \%) \\
92\end{array}$ \\
\hline
\end{tabular}

TABLE II

Comparison of Date of Treatment in Group of Patients

Examined With that in the Whole Series

\begin{tabular}{|cccccc|}
\hline \multirow{2}{*}{$\begin{array}{c}\text { Year of first } \\
\text { treatment }\end{array}$} & \multicolumn{2}{c}{ All patients } & \multicolumn{2}{c|}{ Patients examined } \\
\cline { 5 - 6 } & Number & Per cent & Number & Per cent \\
\hline $1891-1900$ & 4 & $0 \cdot 45$ & 2 & $0 \cdot 75$ \\
$1901-1910$ & 50 & $5 \cdot 6$ & 5 & $1 \cdot 9$ \\
$1911-1920$ & 263 & $29 \cdot 6$ & 50 & $18 \cdot 9$ \\
$1921-1930$ & 290 & $32 \cdot 6$ & 94 & $35 \cdot 65$ \\
$1931-1940$ & 210 & $23 \cdot 6$ & 80 & $30 \cdot 3$ \\
After 1941 & 72 & $8 \cdot 1$ & 33 & $12 \cdot 5$ \\
& 889 & $100 \%$ & 264 & $100 \%$ \\
& & & & \\
\hline
\end{tabular}

TABLE III

Comparison of Age at First Treatment in Cases Examined ANd IN Whole Series

\begin{tabular}{|c|c|c|c|c|}
\hline \multirow{2}{*}{$\begin{array}{l}\text { Age at first } \\
\text { treatment }\end{array}$} & \multicolumn{2}{|c|}{ All cases } & \multicolumn{2}{|c|}{ Cases examined } \\
\hline & Number & Per cent & Number & Per cent \\
\hline Under 3 & 284 & $32 \cdot 4$ & 130) & $49 \cdot 2$ \\
\hline $3-5$ & 155 & $17 \cdot 7$ & 60 & $22 \cdot 7$ \\
\hline $5-10$ & 170 & $19 \cdot 4$ & - & - \\
\hline $5-11$ & - & - & 41 & $15 \cdot 5$ \\
\hline Over 1 ) & 266 & $30 \cdot 4$ & - & - \\
\hline Over 11 & -- & - & 33 & $12 \cdot 5$ \\
\hline \multirow[t]{2}{*}{ Unclassified } & $\begin{array}{r}875 \\
14\end{array}$ & & 264 & \\
\hline & 889 & & & \\
\hline
\end{tabular}

vol. 35 B, No. 3, AUgust 1953 
The reliability of the sample-To the extent of the evidence provided, therefore, the 264 cases actually examined were a fair sample of the whole. This sample, however, tended to be drawn from those who were first treated in more recent years, as shown in Table II.

The comparison indicates that the period of follow-up has been shorter in the sample; hence the results would tend to be more favourable. It may also reasonably be inferred that the quality of treatment for the sample was rather better because it was more recent; the results would again tend to be more favourable.

Furthermore, this sample tends to be drawn from those first treated earlier in life, as shown in Table III.

The condition was therefore treated earlier in the sample cases and the results would tend to be more favourable.

It will be gathered from the above arguments and figures that the patients examined tend to represent a more favourable section of the total and give a more favourable picture of the effects of the regimen of treatment.

Heredity - In twenty-eight of the 264 patients (10.6 per cent) there was an anterior or contemporaneous family history of congenital dislocation, a rather lower figure than that obtaining, namely 17.4 per cent, at the Rizzoli Institute, Bologna (Scaglietti 1939). One relative was affected in twenty-four of the twenty-eight cases, and two in each of the other four. The relationships of patients to the affected members of their families were as follows: great grandparents and grandparents 6 , parents 7 , uncles and aunts 6 , siblings 6 , cousins 7 . There is, therefore, a direct hereditary influence (cases in which a parent is affected) in a quarter of the familial cases and in $\mathbf{2 \cdot 6 5}$ per cent of the series. At the Rizzoli Institute the figure corresponding to the latter was 6.69 per cent; and Poli's figure for Milan, quoted by Scaglietti (1939), was $7 \cdot 57$ per cent.

Two of the twenty-eight $(7 \cdot 1$ per cent) were only children whereas fifty-five $(23 \cdot 3$ per cent) of the 236 with no family history were only children. The other twenty-six with a family history had ninety-eight siblings, and the other 181 with no family history 472 . Patients with a family history therefore belonged to families having an average of 3.5 children, while those without a family history belonged to families with an average of $\mathbf{2 \cdot 2}$. This seems to indicate that the presence of the anomaly in the family tree was no deterrent to the rearing of larger families, though it is in contrast with the figures relating to the younger generation of patients.

Fifteen of the twenty-eight patients who had a family history are married and have so far produced twenty-four children, none of whom is affected. Sixty-seven of the 236 patients with no family history are married and have produced ninety-one children, of whom four are suffering from congenital dislocation. In one the condition is bilateral, as in the parent, and in the other three the side affected is the same as in the parent.

Thus eighty-two parents had four affected children out of a total of 115. In this small series the risks of transmission were therefore as follows: $3 \cdot 5$ per cent of the children of affected parents will themselves be affected; $\mathbf{5} \cdot 0$ per cent of affected parents will have a child who is affected. A previous negative history is no guarantee against the appearance of the deformity.

Of the 264 patients eighty-two (31 per cent) are married and 182 unmarried. Fifteen of the eighty-two have a family history; twenty-two of the eighty-two families are childless, the remaining sixty families having 115 children in all. This makes an average of $1 \cdot 4$ children to each family, which, even allowing for the fact that some of these families were not complete, is lower than the figure for the country as a whole. According to the Report of the Royal Commission on Population (1949) dealing with the years between 1925-1929 the latter is $\mathbf{2 \cdot 2}$ per family.

Of the 182 unmarried patients sixty-eight were under the age of twenty and would normally be expected to be single, although, in fact, two patients under the age of twenty are married but childless. 
LATE RESULTS OF TREATMENT OF CONGENITAL DISLOCATION OF THE HIP

Co-existing conditions-Of the congenital conditions present eight ( 3 per cent) were club feet, and a like number of patients were mentally deficient (Table IV). The incidence of talipes is similar to that found by Scaglietti $(1932,1939)$ at the Rizzoli Institute. Anterior poliomyelitis had affected ten patients; this is a higher incidence than obtained in the general population but its significance, if any, is unknown.

TABLE IV

Patients Examined

Other co-existing conditions

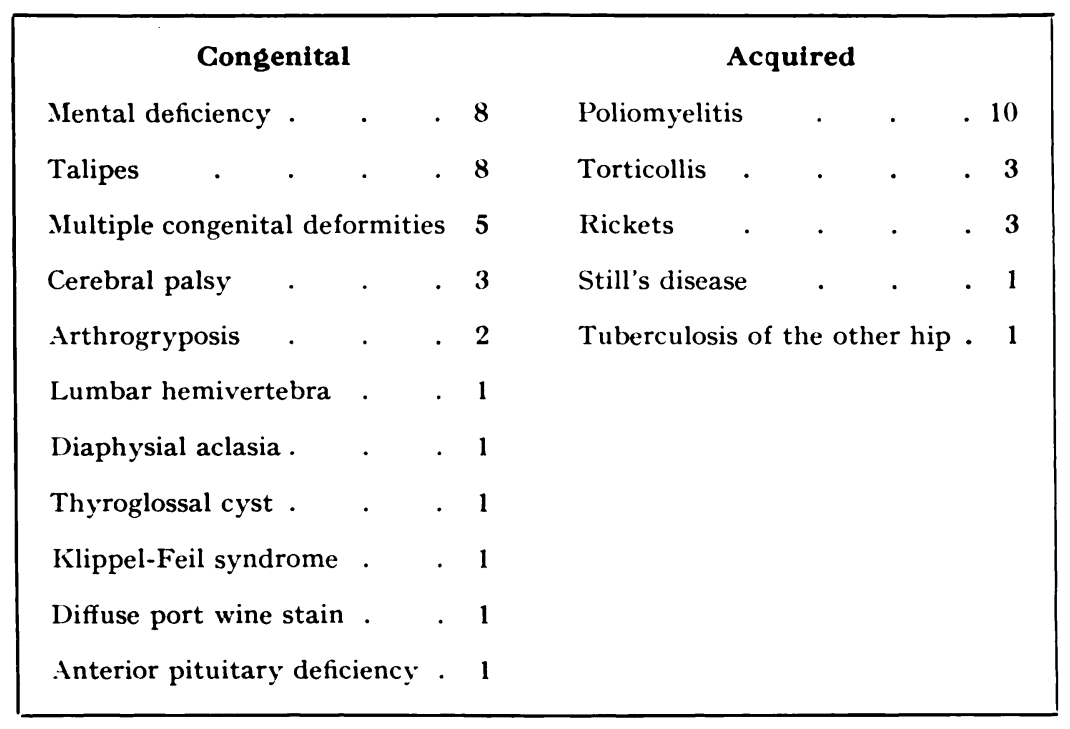

Birth presentation - Table $\mathrm{V}$ gives the mode of presentation of the foetus at the time of birth. Of the ninety-five cases in which this was known forty were breech presentations. Even assuming that this was the total number of breech presentations in all of the 264 cases the percentage is 15; the actual figure is probably higher. When it is recalled that the usual

TABLE $V$

Patients Examined

Birth presentations (264 patients)

\begin{tabular}{|lrrr}
\hline Head &. &. & 54 \\
Breech &. &. & 40 \\
Caesarean. &. &. & 1 \\
Unknown. &. &. & 169 \\
\hline
\end{tabular}

incidence of breech presentations is $\mathbf{1 \cdot 2 5}$ per cent it is hard to avoid the conclusion that there is some factor responsible for the high proportion of breech deliveries associated with dislocation of the hip.

\section{DETAILS OF THE FOLLOW-UP PERIOD}

Table VI gives the ages of the patients when they first attended for treatment at the Royal National Orthopaedic Hospital. Under 2 per cent came during the first year of life.

vol. 35 B, No. 3, AUGUST 1953 
About one-third attended in the second and third years, another third between the third and tenth years, and a further third after ten years.

Table VII shows the decades in which patients were first seen at the hospital. The reason for the falling off of the figures in the decade starting 1931 is that no patient born after the end of 1936 was reviewed. Thus of the cases first attending after 1941 only those

TABLE VI

\section{All Patients}

Age when first treated at the Royal National Orthopaedic Hospital (889 patients)

\begin{tabular}{|lcc|}
\hline Age (years) & Number & Per cent \\
\cline { 1 - 2 } Under 1 & 15 & $1 \cdot 7$ \\
$1-3$ & 269 & $30 \cdot 7$ \\
$3-5$ & 155 & $17 \cdot 7$ \\
$5-10$ & 170 & $19 \cdot 4$ \\
Over 10 & 266 & $30 \cdot 4$ \\
Unclassified & 14 & - \\
\hline
\end{tabular}

TABLE VII

All Patients

Decades in which patients were first seen at the Royal National Orthopaedic Hospital (889 patients)

\begin{tabular}{|cc|}
\hline Decade & Number of patients \\
\hline $1891-1900$ & 5 \\
$1901-1910$ & 263 \\
$1911-1920$ & 290 \\
$1921-1930$ & 210 \\
$1931-1940$ & 72 \\
After 1941 & \\
\hline
\end{tabular}

born before 1936 are included; they came at a late stage of their condition and were of necessity atypical. It will be noticed that during the years 1911 to 1940 about twenty-seven new patients were seen annually.

Of those re-examined 130 , or nearly half, had first come under treatment before the age of three (Table VIII) and roughly a further quarter under the age of five years.

TABLE VIII

Patients Examined

Age when first treated at the Royal National Orthopaedic Hospital or elsewhere (264 patients)

\begin{tabular}{|ccc|}
\hline Age (years) & Number & Per cent \\
\hline Under 3 & 130 & $49 \cdot 2$ \\
$3-5$ & 60 & 22.7 \\
$5-7$ & 28 & $10 \cdot 6$ \\
$7-9$ & 8 & 3 \\
$9-11$ & 5 & 1.9 \\
Over 11 & 33 & 12.5 \\
\hline
\end{tabular}

TABLE IX

Age at Time of Review

(264 patients)

\begin{tabular}{|c:c|}
\hline Age (years) & Number of patients \\
\hline $11-20$ & 70 \\
$21-30$ & 76 \\
$31-40$ & 64 \\
$41-50$ & 32 \\
$51-60$ & 11 \\
$61-70$ & 10 \\
Over 70 & 1 \\
\hline
\end{tabular}

Table IX shows the ages of patients at the time of the review; seventy were under twenty and fifty-four were over forty; 140, or over one-half the number, were between twenty and forty.

Table $\mathrm{X}$ shows the intervals between the completion of treatment and the final review. Calculations have been made from the time when plaster-of-paris fixation was discontinued, 
TABLE X

FOLIOW-UP INTERVAL

(264 patients)

\begin{tabular}{|c|c|}
\hline Interval (years) & Number of patients \\
\hline Less than 10 & 10 \\
$11-15$ & 73 \\
$16-20$ & 58 \\
$21-25$ & 36 \\
$26-30$ & 35 \\
$31-35$ & 30 \\
$36-40$ & 12 \\
$41-45$ & 2 \\
$46-50$ & 5 \\
More than 50 & 3 \\
\hline
\end{tabular}

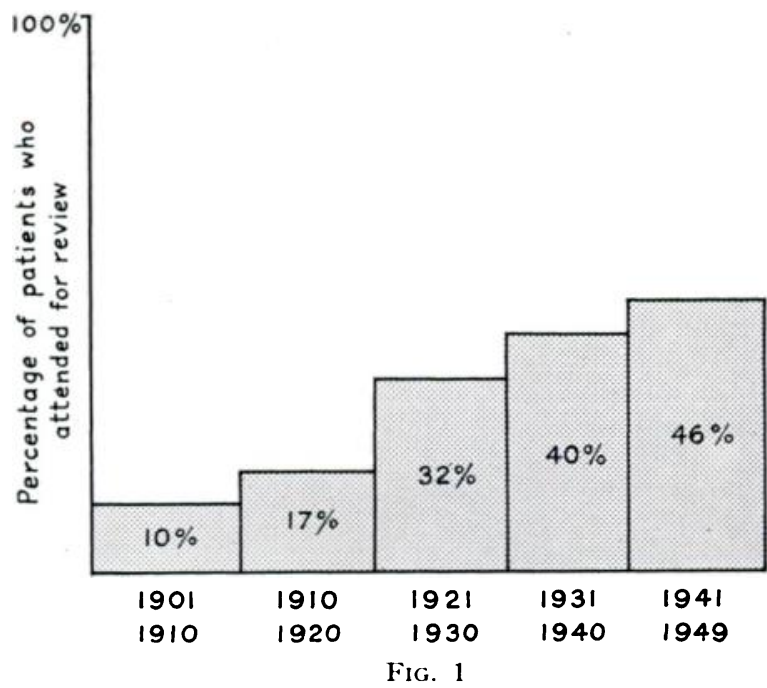

Time of first attendance.

in those cases in which it had been used. In other cases the follow-up period dates from the year when the patient first attended a hospital for treatment.

Each succeeding decade shows a steadily increasing proportion of patients treated attending for re-examination (Fig. 1).

\section{ASSESSMENT OF RESULTS}

For the purpose of assessing results hips were classified in accordance with a scheme derised by St J. D. Buxton (personal communication) in connection with chronic arthritis of the hip, and slightly modified by us for this review. It resembles the method of grading described by Merle d'Aubigné (1952). The results are classified as follows:

\section{Pain (P)}

1. Severe.

2. Severe on movement; little at rest.

3. Some on movement; none at rest.

4. Slight on movement.

5. None.

\section{Function (F)}

1. Walks short distances only, with difficulty.

2. Walks half a mile; noticeable dip.

3. Walks two miles; slight dip.

4. Slight impairment of function.

5. Normal.

\section{Movement (M)}

1. I.ittle or none.

2. Less than 50 per cent : fixed deformity.

3. More than 50 per cent movement; no fixed deformity.

4. Slight limitation of movement; no fixed deformity.

5. Full.

\section{Radiographic anatomy (X)}

1. Dislocation; ankylosis; osteotomy; excision head and neck.

2. Marked subluxation; gross deformity.

3. Slight subluxation; much deformity.

4. Slight subluxation; some deformity.

5. Almost normal.

vol. 35 B, No. 3, AUgust 1953 
A normal joint would thus be described as P5, F5, M5 and X5, scoring a total of 20 points. Each joint examined was allotted marks in this way, and from a consideration of the severity of pain, the amount of activity enjoyed, the range of movement and the radiographic findings, the joints were finally classified into four groups:

$\mathrm{E}$-excellent or very good, where points obtained were 17 or over.

$G$-good, where the points obtained were between 16 and 14 .

$\mathrm{F}$-fair, where the points obtained were between 13 and 11 .

$\mathrm{P}$-poor, where the points obtained were 10 or less.

TABLE XI

General Analysis of Treatment

(264 patients)

\begin{tabular}{|c|c|c|}
\hline \multicolumn{2}{|l|}{ Treatment } & Number of patients \\
\hline Closed reduction & . & 155 \\
\hline Failed manipulation followed immediately by & peration & 6 \\
\hline Closed reduction followed by operation & . & 23 \\
\hline Closed reduction; operation some years later & . & 38 \\
\hline No attempt at reduction; later operation & . & 15 \\
\hline No treatment. & . & 27 \\
\hline
\end{tabular}

TABLE XII

Patients Examined

209 patients treated at the Hospital from the beginning

\begin{tabular}{|ccc|}
\hline $\begin{array}{c}\text { Age in } \\
\text { years }\end{array}$ & $\begin{array}{c}\text { Treatment designed to } \\
\text { reduce the dislocation }\end{array}$ & $\begin{array}{c}\text { Treatment not designed to } \\
\text { reduce the dislocation }\end{array}$ \\
\cline { 1 - 2 } $\begin{array}{c}\text { red } \\
3-5\end{array}$ & 100 & $\begin{array}{c}1 \\
\text { (Parents refused treatment) } \\
\text { (Not expected to live) }\end{array}$ \\
$5-7$ & 42 & - \\
$7-9$ & 21 & - \\
$9-11$ & 7 & - \\
Over 11 & 2 & 35 \\
\cline { 2 - 3 } & - & 37 \\
\hline
\end{tabular}

GENERAL ANALYSIS OF TREATMENT

Of the $\mathbf{2 6 4}$ patients re-examined $15 \tilde{5}$ (Table XI) were treated by closed reduction alone. Six patients were operated on immediately after the failure of manipulation.

In twenty-three patients the period of plaster fixation was followed directly by operation, though sometimes the latter did not take place until four years from the time when treatment began. The infrequency of these operations and the protraction of the period of plaster fixation before they were undertaken is in sharp contrast with present day practice, when 
every effort is made to determine within a year of the original closed reduction whether or not operation will be required to ensure a stable joint.

In thirty-eight cases operation was performed some years after the conclusion of the closed treatment.

In forty-two cases no attempt was made to reduce the dislocation but in fifteen of them operation was required sooner or later; twenty-seven had no treatment of any kind.

TABLE XIII

Patients Examined

172 patients (229 hips) treated from the first at the Royal National Orthopaedic Hospital

\begin{tabular}{|c|c|c|c|c|c|c|}
\hline \multirow[t]{2}{*}{ Age } & \multicolumn{2}{|c|}{$\begin{array}{l}\text { Manipulative } \\
\text { reduction } \\
\text { alone }\end{array}$} & \multicolumn{2}{|c|}{$\begin{array}{l}\text { Manipulation } \\
\text { followed by } \\
\text { operation }\end{array}$} & \multicolumn{2}{|c|}{$\begin{array}{c}\text { Treatment } \\
\text { abandoned }\end{array}$} \\
\hline & Patients & Hips & Patients & Hips & Patients & Hips \\
\hline $0-3$ & 90 & 117 & 9 & 11 & 1 & 2 \\
\hline $3-5$ & 32 & 47 & 8 & 12 & 2 & 2 \\
\hline $5-7$ & 18 & 22 & 2 & 3 & 1 & 2 \\
\hline $.7-9$ & 4 & 6 & 3 & 3 & - & - \\
\hline $9-11$ & 一 & - & 2 & 2 & - & - \\
\hline Total number of patients & 144 & & 24 & & 4 & \\
\hline Total number of hips & & 192 & & 31 & & 6 \\
\hline
\end{tabular}

TABLE XIV

Patients Examined

Fifty-five patients (seventy-six hips) treated early elsewhere

\begin{tabular}{|c|ccccc|c|}
\hline Age & $\begin{array}{c}\text { Manipulative } \\
\text { reduction } \\
\text { alone }\end{array}$ & $\begin{array}{c}\text { Manipulation } \\
\text { followed by } \\
\text { operation }\end{array}$ & $\begin{array}{c}\text { Treatment } \\
\text { abandoned }\end{array}$ \\
\hline $0-3$ & Patients & Hips & $\begin{array}{c}\text { Patients } \\
3-5\end{array}$ & $\begin{array}{c}\text { Hips } \\
\text { Patients }\end{array}$ & Hips \\
\hline $5-7$ & 13 & 19 & 2 & 3 & 1 & 1 \\
$7-9$ & 5 & 7 & 1 & 1 & - & - \\
$9-11$ & - & - & - & - & - & - \\
\hline Total number of patients & 49 & & 5 & & 1 & - \\
\hline Total number of hips & & 69 & & 6 & & 1 \\
\hline
\end{tabular}

Turning now to the patients treated from the first at the Orthopaedic Hospital, there were 209 cases, in 172 of which the aim was reduction of the dislocation (Table XII). Reduction was attempted in no less than nine cases over the age of seven. The details of the treatment at this early stage are shown in Table XIII.

In fifty-five cases the early treatment was carried out elsewhere; the details of treatment in relation to age are shown in Table XIV.

VOL. 35 B, No. 3, AUgust 1953 
It will be seen that a total of 193 patients with 261 dislocated hips were treated by manipulative reduction alone while twenty-nine had manipulation followed by operation after a relatively short period. Of the former number, thirty-eight had operative treatment at a subsequent and relatively late period, leaving, up to the time of review, 155 treated by manipulative reduction alone.

\section{DETAILED ANALYSIS OF TREATMENT}

Manipulation-One hundred and ninety-three patients were treated by closed manipulation and of these thirty-eight underwent operation later. Of the 155 patients treated by closed methods alone (Table XV) 108 presented unilateral and forty-seven bilateral dislocations.

TABLE XV

Patients Examined

Results of manipulative reduction alone

\begin{tabular}{|c|c|c|c|c|c|c|c|}
\hline $\begin{array}{c}\text { Age } \\
\text { (years) }\end{array}$ & Patients & \multicolumn{2}{|c|}{ Bilateral } & \multicolumn{2}{|c|}{ Unilateral } & \multicolumn{2}{|c|}{ All hips } \\
\hline Under 3 & 98 & $\begin{array}{l}\text { Excellen } \\
\text { Good } \\
\text { Fair } \\
\text { Poor }\end{array}$ & 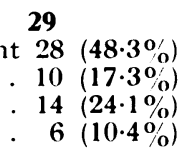 & $\begin{array}{l}\text { Excellen } \\
\text { Good } \\
\text { Fair } \\
\text { Poor }\end{array}$ & 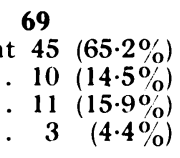 & $\begin{array}{l}\text { Excellent } \\
\text { Good } \\
\text { Fair } \\
\text { Poor }\end{array}$ & $\begin{array}{r}73 \\
. \quad 20 \\
. \quad 25 \\
. \quad 9\end{array}$ \\
\hline $3-5$ & 34 & $\begin{array}{l}\text { Excellen } \\
\text { Good } \\
\text { Fair } \\
\text { Poor }\end{array}$ & 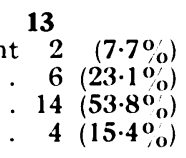 & $\begin{array}{l}\text { Excellen } \\
\text { Good } \\
\text { Fair } \\
\text { Poor }\end{array}$ & 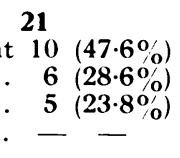 & $\begin{array}{l}\text { 47 } \\
\text { Excellent } \\
\text { Good } \\
\text { Fair } \\
\text { Poor }\end{array}$ & $\begin{array}{r}12 \\
. \quad 12 \\
. \quad 4 \\
. \quad 4\end{array}$ \\
\hline $5-7$ & 19 & $\begin{array}{l}\text { Good } \\
\text { Fair } \\
\text { Poor }\end{array}$ & $\begin{aligned} & 5 \\
& . \quad 2(20 \%) \\
& . \quad 4(40 \%) \\
& . \quad 4(40 \%)\end{aligned}$ & $\begin{array}{l}\text { Excellen } \\
\text { Good } \\
\text { Fair } \\
\text { Poor }\end{array}$ & $\begin{array}{rrr} & 14 & \\
& 6 & (42.9 \%) \\
. & 4 & (28.6 \%) \\
. & 3 & (21 \cdot 4 \%) \\
. & 1 & (7.1 \%)\end{array}$ & $\begin{array}{l}\text { 24 } \\
\text { Excellent } \\
\text { Good } \\
\text { Fair } \\
\text { Poor }\end{array}$ & $\begin{array}{ll} & \\
\text { t } & 6 \\
. & 6 \\
. & 7 \\
. & 5\end{array}$ \\
\hline $7-9$ & 2 & & - & & 2 & $\underset{\text { Fair }}{{ }_{\text {Good }}^{2}}$ & $\begin{array}{l}1 \\
. \quad 1\end{array}$ \\
\hline 9)- 11 & 2 & & - & & 2 & $\begin{array}{l}2 \\
\text { Excellent } \\
\text { Good }\end{array}$ & $\begin{array}{ll}t & 1 \\
\cdot & 1\end{array}$ \\
\hline Totals & 155 & & 47 & & 108 & $\begin{array}{l}202 \\
\text { Excellent } \\
\text { Good } \\
\text { Fair } \\
\text { Poor }\end{array}$ & 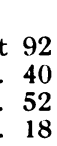 \\
\hline
\end{tabular}

The results in this group are most interesting. In 80 per cent of unilateral dislocations treated before the age of three years the result was good, whereas only 65 per cent of the bilateral dislocations in the same age group were equally satisfactory. Taking the comparison a stage further it is found that 65 per cent of the unilateral dislocations gave excellent results, whereas the corresponding proportion of bilateral dislocations was 48 per cent. The contrast is even more striking for the three to five years age group, in which 76 per cent of unilateral dislocations gave good results as compared with 31 per cent of bilateral dislocations. Similarly, in the five to seven years age group 71 per cent of unilateral dislocations gave good results, whereas only 20 per cent of the bilateral dislocations were good.

Immediate open operation-Six patients in the series were treated by open operation immediately after failure of manipulative reduction. Of the nine hips operated on (Table XVI) 
TABLE XVI

Patients Examined

Results in six patients (nine hips) treated by open operation immediately after failure of manipulation

\begin{tabular}{|c|c|c|c|}
\hline $\begin{array}{c}\text { Age } \\
\text { (years) }\end{array}$ & Patients & Hips & Results \\
\hline $0-3$ & - & - & - \\
\hline $3-5$ & 3 & 5 & $\begin{array}{l}\text { Excellent } \\
\text { Good . } \\
\text { Fair }\end{array}$ \\
\hline $5-7$ & 2 & 3 & $\begin{array}{l}\text { Fair } \\
\text { Poor }\end{array}$ \\
\hline $7-9$ & 1 & 1 & Good \\
\hline $9-11$ & - & - & - \\
\hline
\end{tabular}

five were dealt with by open reduction, there were three shelf operations and one arthroplasty. The open reductions gave one good, three fair and one poor result. The shelves gave one excellent and two good results, whereas the arthroplasty was unsatisfactory.

Manipulation followed by operation-Table XVII shows the results in twenty-three patients who were treated by manipulation followed by operation at times varying between three months and four years after treatment began. In all these patients the operation followed immediately after the period of plaster fixation. The five excellent results all followed shelf operations performed between nine months and two years after the first application of plaster. Three of the six good results followed shelf operations and three followed open reductions. It will be noticed that only thirteen of these hips were operated on within a year of being put into plaster and when, presumably, the conclusion was reached that further immobilisation alone would not cure the condition. Of the bad results (which include fair and poor) in this group seven were in patients operated on before one year, and eight in patients operated on later. This seems to suggest that these cases were either intrinsically unfavourable or that some of them were operated on too late. Against the second supposition is the fact that there were two patients in this group who were operated on after only three months' immobilisation and yet the results were only fair.

Closed reduction, late operation-Thirty-eight patients, presenting forty-four hips (Table XVIII), were treated first by closed reduction but underwent operation some considerable time after coming out of plaster. In the 0-3 years age group 38 per cent showed very good or good results. The average interval between the time when they were first put into plaster and the operation was twelve and a half years. In the 3-5 years age group, 27 per cent showed excellent or good results, the average interval between the time when the patient was first put in plaster and the operation being eleven years. In the 5-7 years age group, $33 \cdot 3$ per cent of the cases showed a very good or good result, the average interval between the time when treatment started and the operation being twelve and a half years. Thus, almost irrespective of age these miscellaneous operations gave a uniform but low proportion of successes.

No reduction attempted: late operation-Fifteen patients were operated on at a later age. Four osteotomies of the Lorenz type, three arthroplasties, two rotation osteotomies, five arthrodeses and two shelf operations were performed. There was one patient on whom bilateral osteotomy of the Lorenz type was carried out; in another an arthroplasty was followed by arthrodesis.

vol. 35 B, No. 3, AUgust 1953 
TABLE XVII

Results in Twenty-three Patients (Twenty-six Hips) Treated by Manipulation Followed by OpERATION

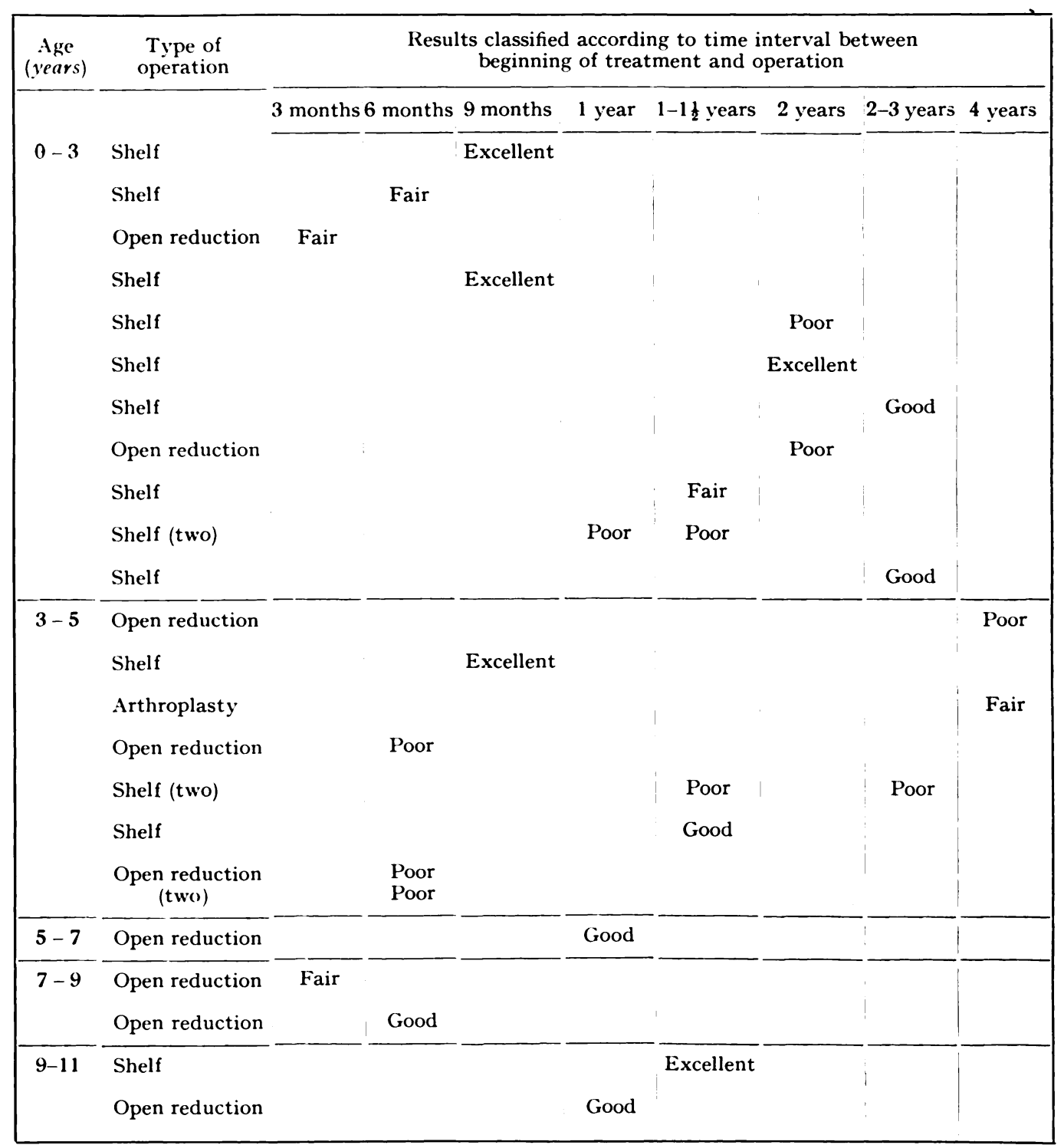

The results in the sixteen hips were as follows: excellent, none; good, three; fair, four; poor, nine.

No treatment-Twenty-seven patients had no specific treatment. The behaviour of the thirty-three hips in this group was as follows: excellent, one; good, fourteen; fair, seven; poor, eleven.

\section{RESULTS OF SPECIFIC OPERATIONS}

Open reduction-Open reduction was carried out on seventeen patients (Table XIX). These operations were usually done because of failure of repeated attempts at manipulative reduction. In three cases, however (one of the patients aged sixteen years sustained a fracture 
TABLE XVIII

Results in Thirty-eight Patients (Forty-four Hips) Treated by Manipulation and Operated on Considerably later

\begin{tabular}{|c|c|c|c|c|c|c|c|}
\hline $\begin{array}{c}\text { Age when } \\
\text { treatment } \\
\text { started } \\
(\text { years })\end{array}$ & Patients & Hips & Operation & & $\begin{array}{l}\text { Average time } \\
\text { interval before } \\
\text { operation } \\
\text { (years) }\end{array}$ & & esults \\
\hline $0-3$ & 18 & 21 & $\begin{array}{l}\text { Osteotomy } \\
\text { Excision of osteophytes } \\
\text { Shelf } \\
\text { Arthrodesis } \\
\text { Rotation osteotomy } \\
\text { Arthroplasty } \\
\text { (one hip was operated } \\
\text { twice) }\end{array}$ & $\begin{array}{l}7 \\
2 \\
6 \\
2 \\
2 \\
4 \\
1 \\
\text { on }\end{array}$ & $12 \frac{1}{2}$ & $\begin{array}{l}\text { Excellent } \\
\text { Good . } \\
\text { Fair } \\
\text { Poor }\end{array}$ & $\left.\begin{array}{c}2 \\
6 \\
6 \\
3 \\
10\end{array}\right\} 38 \%$ \\
\hline $3-5$ & 10 & 11 & $\begin{array}{l}\text { Open reduction } \\
\text { Shelf : } \\
\text { Cup arthroplasty } \\
\text { Arthrodesis : } \\
\text { Osteotomy }: \\
\text { (one hip was operated } \\
\text { twice) }\end{array}$ & $\begin{array}{l}1 \\
4 \\
1 \\
1 \\
1 \\
5 \\
\text { on }\end{array}$ & 11 & $\begin{array}{l}\text { Excellent } \\
\text { Good } \\
\text { Fair } \\
\text { Poor }\end{array}$ & \begin{tabular}{l|l}
1 & $27 \%$ \\
2 & 4 \\
4 &
\end{tabular} \\
\hline $5-7$ & 8 & 10 & 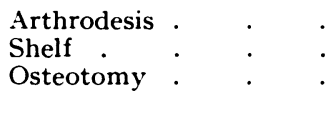 & $\begin{array}{l}4 \\
3 \\
3\end{array}$ & $12 \frac{1}{2}$ & $\begin{array}{l}\text { Excellent } \\
\text { Good } \\
\text { Fair } \\
\text { Poor }\end{array}$ & $\begin{array}{l}1\} 33 \cdot 3 \% \\
2 \nmid 3 \\
5 \\
2\end{array}$ \\
\hline $7-9$ & 2 & 2 & $\begin{array}{l}\text { Osteotomy } \\
\text { Open reduction } \\
\text { Sliding of great trochanter } \\
\text { (one hip was operated } \\
\text { twice) }\end{array}$ & $\begin{array}{l}1 \\
1 \\
1 \\
\text { on }\end{array}$ & $13 \frac{1}{2}$ & $\begin{array}{l}\text { Excellent } \\
\text { Good } \\
\text { Fair } \\
\text { Poor }\end{array}$ & $\frac{-}{1}$ \\
\hline
\end{tabular}

TABLE XIX

Patients Examined

Analysis of open reductions (seventeen cases)

\begin{tabular}{|c|c|c|c|c|c|}
\hline $\begin{array}{c}\text { Age at } \\
\text { operation } \\
\text { (years) }\end{array}$ & Patients & Hips & Reason & \multicolumn{2}{|l|}{ Results } \\
\hline $0-3$ & 3 & 3 & Failed manipulation & $\begin{array}{l}\text { Fair } \\
\text { Poor }\end{array}$ & $\begin{array}{l}1 \\
2\end{array}$ \\
\hline $3-5$ & 5 & 7 & $\begin{array}{l}\text { Primary attempt at } \\
\text { reduction } \\
\text { Failed manipulation } \\
\text { Instability }\end{array}$ & $\begin{array}{l}\text { Fair } \\
\text { Poor }\end{array}$ & $\begin{array}{l}3 \\
4\end{array}$ \\
\hline $5-7$ & 3 & 4 & Failed manipulation & $\begin{array}{l}\text { Good } \\
\text { Fair } \\
\text { Poor }\end{array}$ & $\begin{array}{l}1 \\
1 \\
2\end{array}$ \\
\hline $7-9$ & 4 & 4 & Failed manipulation & $\begin{array}{l}\text { Good } \\
\text { Fair }\end{array}$ & $\begin{array}{l}2 \\
2\end{array}$ \\
\hline $9-11$ & 1 & 1 & Failed manipulation & Excellent & \\
\hline Over 11 & 1 & 1 & $\begin{array}{l}\text { Primary attempt at } \\
\text { reduction (aged 16) }\end{array}$ & Fair & \\
\hline Total & 17 & 20 & & $\begin{array}{l}\text { Excellent } \\
\text { Good : } \\
\text { Fair : } \\
\text { Poor }\end{array}$ & $\begin{array}{l}1 \\
3 \\
8 \\
8\end{array}$ \\
\hline
\end{tabular}


of the femoral neck during the procedure), the operation was the initial attempt to reduce the hip. On only two patients was the operation performed because the hip was found to be unstable though apparently reduced. In three cases the hand of the surgeon had been forced because of a fracture of the femoral neck sustained during manipulation; misguided attempts were made to align the fragments and to reduce the head at the same time, neither objective being achieved.

Hour-glass deformities were noted in six of these cases. The attempted open reduction was abandoned in three cases, in one at the second attempt. In two cases the head was remodelled, and in one a new acetabulum was gouged out; the subsequent history of these cases is dismal.

Four of the twenty hips in this series had excellent or good results. In ten the head subsequently absorbed to a considerable extent, while in one it enlarged after operation.

TABLE XX

Forty-one Osteotomies in Thirty-three Patients

\begin{tabular}{|c|c|c|c|c|c|c|c|c|c|c|c|c|}
\hline \multirow{3}{*}{$\begin{array}{c}\begin{array}{c}\text { Age at } \\
\text { operation } \\
\text { (years) }\end{array} \\
0-10\end{array}$} & \multicolumn{3}{|c|}{ Rotation } & \multicolumn{3}{|c|}{ Abduction } & \multicolumn{3}{|c|}{ Adduction } & \multicolumn{3}{|c|}{$\begin{array}{c}\text { Bifurcation } \\
\text { (Lorenz, MIcMlurray) }\end{array}$} \\
\hline & \multirow{2}{*}{$\frac{\text { Hips }}{3}$} & \multicolumn{2}{|c|}{ Results } & \multirow{2}{*}{$\frac{\text { Hips }}{2}$} & \multicolumn{2}{|c|}{ Results } & \multirow{2}{*}{$\frac{\text { Hips }}{1}$} & \multicolumn{2}{|c|}{ Results } & \multirow{2}{*}{$\frac{\text { Hips }}{3}$} & \multicolumn{2}{|c|}{ Results } \\
\hline & & $\begin{array}{l}\text { Good } \\
\text { Fair } \\
\text { Poor }\end{array}$ & $\begin{array}{l}1 \\
1 \\
1\end{array}$ & & Poor & . 2 & & Poor & . 1 & & $\begin{array}{l}\text { Fair } \\
\text { Poor }\end{array}$ & $\begin{array}{l}2 \\
.1 \\
.\end{array}$ \\
\hline $10-20$ & 4 & $\begin{array}{l}\text { Excellen } \\
\text { Good } \\
\text { Fair } \\
\text { Poor }\end{array}$ & $\begin{array}{l}1 \\
\cdot \begin{array}{l}1 \\
1 \\
1\end{array}\end{array}$ & 5 & $\begin{array}{l}\text { Good } \\
\text { Fair } \\
\text { Poor }\end{array}$ & $\begin{array}{l}.1 \\
.2 \\
.2\end{array}$ & 1 & Poor & . 1 & 8 & $\begin{array}{l}\text { Good } \\
\text { Fair } \\
\text { Poor }\end{array}$ & $\begin{array}{l}.1 \\
.52 \\
.5\end{array}$ \\
\hline $20-30$ & 2 & Poor & 2 & 1 & Poor & .1 & - & - & & 2 & $\begin{array}{l}\text { Fair } \\
\text { Poor }\end{array}$ & $\begin{array}{l}.1 \\
.1\end{array}$ \\
\hline $30-40$ & - & - & & 3 & $\begin{array}{l}\text { Good } \\
\text { Fair } \\
\text { Poor }\end{array}$ & $\begin{array}{l}.1 \\
.1 \\
.1\end{array}$ & - & - & & 3 & $\begin{array}{l}\text { Fair } \\
\text { Poor }\end{array}$ & $\begin{array}{l}.1 \\
.2\end{array}$ \\
\hline $40-50$ & - & - & & 2 & Poor & . 2 & - & - & & 1 & Poor & . 1 \\
\hline Total & 9 & & & 13 & & & 2 & & & 17 & & \\
\hline
\end{tabular}

One patient had three osteotomies.

Six patients had two osteotomies each.

Twenty-six patients had one osteotomy each.

Eleven hips redislocated shortly after operation. In two cases the hip became extremely stiff soon after operation. In one Soutter's operation was required for a flexion deformity on both sides.

Four patients underwent subtrochanteric osteotomy subsequently to mitigate the degree of instability. In one case the resulting fixed adduction necessitated a later abduction osteotomy. On a boy aged sixteen a second operation was performed six years later, when the head was trimmed down to half its size and placed into what remained of the acetabulum; the end-result was fair.

Osteotomy-Thirty-three patients were subjected to a total of forty-one osteotomies (Table XX). Nine of these were rotation osteotomies; three were performed when the patient was less than ten years old, four between the ages of ten and twenty years. In three of them the site of operation was in the lower third, and the results in all cases were good. In three the site of operation was the middle third; the result in one case was excellent-in the other 
two cases fair. In the remaining three hips, where the osteotomy was at the level of the upper third, the results were all poor-this is partly accounted for by the circumstance that two of these were performed on the femora of a child with multiple congenital deformities.

The fragments were wired on one occasion and plated in two others. In one case (two hips) the operations were done two years after the patient had first been put into plaster and six months after a shelf operation had been done on one side. All the other osteotomies were done a considerable time after the patient had first been treated by manipulative reduction.

Thirteen abduction osteotomies were performed, four for pain, six for instability and three for adduction deformity. The results were almost uniformly disappointing. In most cases the poor result was due to the original stiffness of the joint, but some of these patients were most unfortunate in ending up with a hip that was stiff in abduction, a most crippling deformity. The patient can only walk by tilting the pelvis so as to bring the abducted femur into a vertical position; in order to preserve his balance he acquires a compensatory scoliosis convex to the affected side, and when walking he has to swing the unaffected leg in a wide and grotesque arc, before bringing it down for the next step. In one unhappy case an adduction osteotomy was performed on the relatively sound side in order to bring the limb closer to its abducted fellow when the latter was taking weight. This made walking less ungainly but rendered permanent a considerable degree of pelvic tilt and a gross compensatory scoliosis.

Adduction osteotomies were performed on two patients, both for stiffness of the hip in abduction; in one patient following an open reduction and reshaping of the femoral head, which had been complicated by a mild infection; and in the other resulting from application of a spica in abduction for a prolonged period in a girl of twelve. The result in both was very poor.

A Lorenz type of osteotomy was carried out on seventeen hips, eight of them on patients between ten and twenty years. Eleven were for the relief of instability, four for flexion and adduction deformities and two for pain and stiffness in the joint. The results of these operations were disappointing, though symptoms and gait were improved in eight cases. Eight patients were unaware of any improvement. In one the operation was followed by an ankylosis of the joint in adduction; this patient was operated on at the age of forty-two, and the radiographs of her hips showed changes resembling those seen in ankylosing spondylitis.

One patient was subjected to three osteotomies on her two hips in order to correct flexion deformities; and six patients had two osteotomies each.

Shelf operations-Thirty-seven shelf operations were performed on thirty-six hips (Table $\mathrm{XXI}$ ). The results were, on the whole, much better than those seen after other operative procedures; twenty-two (6l per cent) were good. No less than twenty-four of these operations were done after the age of five, and the proportion of good results was much the same before and after what is regarded-it would appear erroneously-as the upper age limit for the operation. All of these shelf operations were performed because of the inadequacy of the acetabular roof, and in twenty-six for instability that was clinically apparent.

Table XXII shows the sites of the shelves. An anatomically accurate lip was constructed in nine operations, and the results were correspondingly good- -90 per cent. The shelf was slightly raised in twelve, and much too high in fourteen. The percentage of excellent and good results in these cases was 58 per cent and 57 per cent respectively: thus it appears that the periarticular disturbance resulting from the operation contributes appreciably to the subsequent stability of the joint.

The Bruce Gill $(1928,1935)$ type of shelf was constructed in twenty-two cases; a curved flap of iliac bone was turned down and held with a wedge also taken from the ilium. In two cases tibial bone was used for the wedge. In two other cases the iliac flap was turned down but no wedge was used. In a further eleven cases no record is available as to whether a wedge was used or whether the flap was left unsupported at the hinge.

vol. $35 \mathrm{~B}$, xo. 3 , August 1953 
TABLE XXI

Shelf Operations

Thirty-three patients (thirty-six hips), thirty-seven operations

\begin{tabular}{|c|c|c|c|c|}
\hline $\begin{array}{c}\text { Age at } \\
\text { operation } \\
\text { (years) }\end{array}$ & Patients & Hips & Results & \\
\hline $0-3$ & 5 & 6 & $\begin{array}{l}\text { Excellent } \\
\text { Fair } \\
\text { Poor }\end{array}$ & $\begin{array}{l}2 \\
1 \\
3\end{array}$ \\
\hline $3-5$ & 6 & 6 & $\begin{array}{l}\text { Excellent } \\
\text { Good } \\
\text { Fair }\end{array}$ & $\begin{array}{l}1 \\
4 \\
1\end{array}$ \\
\hline $5-7$ & 10 & 11 & $\begin{array}{l}\text { Excellent } \\
\text { Good } \\
\text { Fair } \\
\text { Poor }\end{array}$ & $\begin{array}{l}4 \\
3 \\
1 \\
3\end{array}$ \\
\hline $7-9$ & 5 & 5 & $\begin{array}{l}\text { Excellent } \\
\text { Good } \\
\text { Poor }\end{array}$ & $\begin{array}{l}1 \\
3 \\
1\end{array}$ \\
\hline $9-11$ & 2 & 3 & Fair & 3 \\
\hline Over 11 & 5 & 5 & $\begin{array}{l}\text { Excellent } \\
\text { Good } \\
\text { Fair }\end{array}$ & $\begin{array}{l}1 \\
3 \\
1\end{array}$ \\
\hline Total & 33 & 36 & & \\
\hline
\end{tabular}

Three cases appear twice in different age groups.

In one case two operations were performed on the same side, the second after an interval of eight years. The result given is the final one.

\section{TABLE XXII}

Analysis of Shelf Oferations with Regard to Site of Shelf (Thirty-seven operations on thirty-six hips)

\begin{tabular}{|c|c|c|c|}
\hline & & Hips & Result \\
\hline Site unknown & . & 1 & Poor .1 \\
\hline Much too high & . & 14 & \begin{tabular}{ll|l} 
Excellent & 4 & $57 \%$ \\
Good & 4 & $57 \%$ \\
Fair & .3 & \\
Poor & .3 &
\end{tabular} \\
\hline Slightly high & . & 12 & \begin{tabular}{ll|l} 
Excellent & 2 & $58 \%$ \\
Good & 5 & $5 \%$ \\
Fair & .3 & \\
Poor & .2 &
\end{tabular} \\
\hline Anatomical. & . & 9 & $\begin{array}{l}\text { Excellent } 4 \\
\text { Good } \\
\text { Poor } \\
\text { Poor }\end{array}$ \\
\hline
\end{tabular}

In one case there were two operations on the same side; the result given is the final one. 
The timing of the operation in relation to the initiation of treatment is shown in Table XXIII. Seventy-five per cent of the operations performed within the first year gave excellent or good results; 45 per cent of the operations between one and three years were equally good; and 78 per cent of the shelves constructed after the lapse of three years. Thus the scope of the operation appears to be considerably greater than we have recently come to believe.

TABLE XXIII

Timing of Shelf Operations in Relation to the Initiation of Treatient (Thirty-seven operations on thirty-six hips)

\begin{tabular}{|c|c|c|c|}
\hline \multicolumn{2}{|c|}{$\begin{array}{l}\text { Interval after first } \\
\text { application of plaster }\end{array}$} & Hips & Result \\
\hline 1 year or less & . & 8 & \begin{tabular}{ll|l} 
Excellent & 4 & $75 \%$ \\
Good &. & 2
\end{tabular} \\
\hline 1-3 years & . & 14 & \begin{tabular}{ll|l} 
Excellent & 3 & $43 \%$ \\
Good & 3 & 4 \\
Fair &. & \\
Poor & 5 &
\end{tabular} \\
\hline 3-7 years & . & 8 & $\left.\begin{array}{ll}\text { Excellent } & 2 \\
\text { Good } & 5\end{array}\right\} 87 \cdot 5 \%$ \\
\hline Over 7 years & . & 6 & 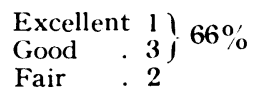 \\
\hline
\end{tabular}

In one case there were two operations on the same side; the result given is the final one.

Thirteen shelves were entirely absorbed, yet in five of these cases the result was good. Fourteen were partly absorbed, the excellent and good results numbering ten. Nine shelves were unabsorbed, and eight of these gave excellent or good results. Here is further evidence, in addition to that furnished by the levels of the shelves, which indicates that soft tissue changes, in the main fibrosis, must contribute considerably to the stability of the joint which is the aim of the operation.

\section{THE C.E. ANGLE}

The C.E. angle was first described by Wiberg (1939) and elaborated for the hips of younger patients by Severin (1941). It is the angle between a line drawn through the centre (C) of the femoral head in the longitudinal axis of the body and another line joining this centre to the lateral edge (E) of the acetabular roof (Fig. 2). This angle is the measure of the extent to which the acetabulum contains the femoral head. After fourteen years of age 25 degrees is the lowest figure for the normal hip. From 20 to 25 degrees is an "uncertain" range, in that there is a tendency for the hip to subluxate; and figures below $\mathbf{2 0}$ degrees are definitely abnormal. This measurement is useful as an expression of the development of the acetabular roof and of the stability of the femoral head in its socket.

The C.E. angle on the affected side was measured in 143 cases in our series, all of them over the age of fourteen. In forty-six the angle was 2.5 degrees or more, and in ten of these there was some degree of

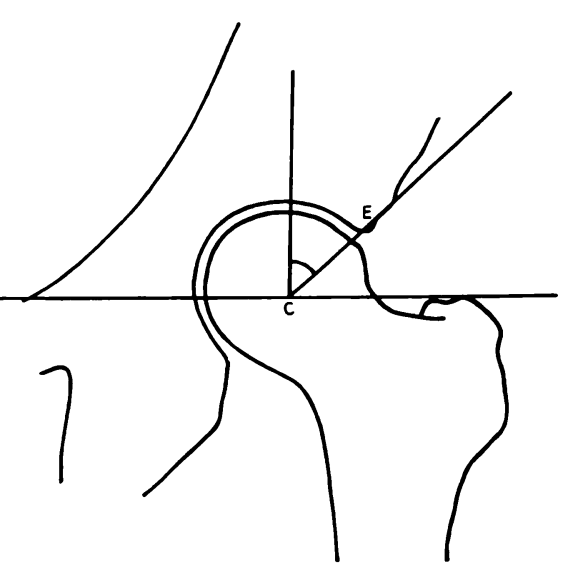

FIG. 2

Diagram showing the C.E. angle.

vol. $35 \mathrm{~B}$, No. 3 , ACgest 1953 
subluxation. In fifteen the angle was between 20 and 25 degrees, the "uncertain " range of Severin; seven had subluxated. Forty-three hips had a C.E. angle of between 10 and 20 degrees, and twenty-six had subluxated. Thirty-five of the thirty-nine hips with a (.E. angle of less than 10 degrees had subluxated. Thus although a good acetabular roof

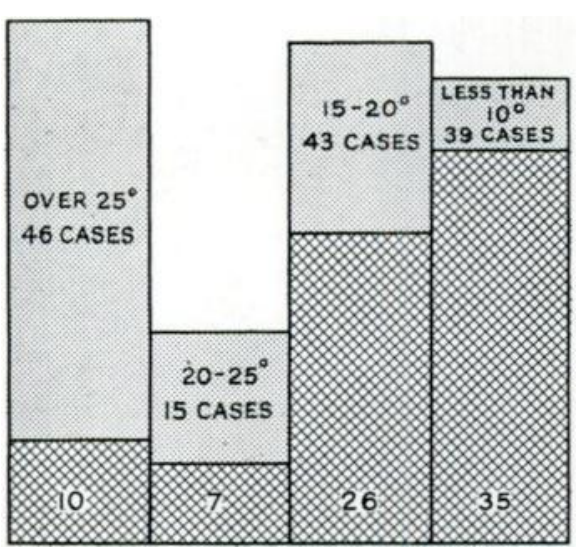

Fig. 3

Relation of the C.E. angle to subluxation. The cross-hatched areas represent cases in which subluxation occurred.

is a most important factor in the maintenance of a stable reduction, it is not an absolute safeguard against subluxation (Fig. 3).

The C.E. angle on the sound side was measured in cases of unilateral dislocation. The following variations were found: the angle was is degrees in four cases; between 5 and 10 degrees in four cases; 10 to 15 degrees in nine cases; 15 to 20 degrees in eleven cases; and 20 to 25 degrees in three cases.

Thus in twenty-eight out of 172 " sound" hips, one would suppose that a well marked tendency to subluxation was present, while three cases were in the "uncertain" group. Here, therefore, is evidence from the opposite direction that an acetabulum of good shape is not indispensable to the stability of the hip. However, the thirty-one cases mentioned above might well be considered to show minor degrees of aplasia on the supposedly sound side, the sort of condition which leads not infrequently to osteoarthritis at a relatively early age.

\section{ANTEVERSION}

The other important anatomical feature in relation to stability of reduction is anteversion of the upper end of the femur, more especially the femoral neck. An attempt was therefore made to estimate the degree of anteversion in each of the cases examined, and to assess its possible significance. Seddon and Trevor (unpublished work) have found that even in the early case of congenital dislocation the various methods of estimating anteversion are surprisingly unreliable when checked by the accurate measurements made at operation. Thus it would be improper to give figures carrying an appearance of refinement. A well known simple clinical method of measurement was used, and all but grossly abnormal figures were disregarded. The patient lay face down with the knees bent at right angles; the examiner held one ankle in one hand, the other hand being placed over the great trochanter. The foot was then moved through an arc until the prominence of the trochanter was maximal. The deviation of the line of the tibia from the vertical was then measured and compared with that on the opposite side, an angle of more than 45) degrees being considered abnormal. In bilateral cases such a comparison is not possible, and one must be content with direct measurement, an inclination of not less than 60 degrees from the vertical being considered significant.

A radiographic method was used in some bilateral cases, and when limitation of medial rotation was a hindrance to clinical measurement.

One hundred and twenty-eight ( 83 per cent) of the 154 hips which showed a notable degree of anteversion were associated with more or less subluxation of the head or with frank dislocation.

The unilateral cases are the best group for analysis. Ninety-five (5i) per cent) of 17.2 unilaterally affected hips showed anteversion. Twelve of these cases had had no carly treatment; eighty-three treated hips ( 52.2 per cent), therefore, showed a significant 
degree of anteversion. Fifty-eight (70 per cent) of these anteverted hips had subluxated (Table XXIV).

Of the seventy-seven unilateraliy affected hips which showed no anteversion eighteen had had no treatment; two others are excluded on account of inadequacy of the case notes;

TABLE XXIV

Relation of ANteversion to Subluxation in 140 Treated Hips

\begin{tabular}{|c|c|c|c|c|}
\hline & \multicolumn{2}{|c|}{ Anteverted (83) } & \multicolumn{2}{|c|}{ Not anteverted (57) } \\
\hline Subluxated & & $(70 \%)$ & 27 & $(47 \cdot 4 \%)$ \\
\hline Not subluxated & 25 & $(30 \%)$ & 30 & $(52.6 \%)$ \\
\hline
\end{tabular}

twenty-seven (or nearly half) of the remaining fifty-seven treated hips showed some degree of subluxation. The difference in the ratios is just sufficient to warrant the assumption that anteversion is a factor in causing subluxation after reduction.

\section{OSTEOARTHRITIS}

One hundred and thirty-eight patients showed radiographic evidence of osteoarthritis. The relationship in $\mathbf{1 3 6}$ of these cases between the configuration of the joint at the time of examination and its function is set out in Table XXV. As would be expected, the figures suggest that the better the anatomical state the better the function as a whole.

TABLE XXV

Relation of Anatomy to Function in 136 Cases of Osteoarthritis, and Relation of Anatomy to Pain in Seventy-Seven Cases in which there was a Complaint of Pain

\begin{tabular}{|c|c|c|c|c|c|c|c|c|}
\hline & \multirow{2}{*}{$\begin{array}{c}\text { Total } \\
\text { number }\end{array}$} & \multicolumn{5}{|c|}{ Function } & \multirow{2}{*}{$\begin{array}{l}\text { Number } \\
\text { with } \\
\text { pain }\end{array}$} & \multirow{2}{*}{$\begin{array}{l}\text { Percentage } \\
\text { with } \\
\text { pain }\end{array}$} \\
\hline & & F5 & F4 & F3 & $\mathrm{F} 2$ & $\mathrm{~F} 1$ & & \\
\hline $\begin{array}{l}\text { Dislocated (femoral head one inch or more above } \\
\text { line of acetabulum) }\end{array}$ & 59 & - & 9) & 31 & 12 & 7 & 37 & 63 \\
\hline $\begin{array}{l}\text { Subluxation (head half to one inch above line of } \\
\text { acetabulum) }\end{array}$ & 30 & 1 & 4 & 16 & 8 & 1 & 17 & 57 \\
\hline $\begin{array}{l}\text { Slight subluxation (head less than half an inch } \\
\text { above line of acetabulum) }\end{array}$ & 30 & 4 & 8 & 8 & 10 & - & 16 & 53 \\
\hline Concentric . & 17 & 9 & - & 3 & 5 & - & 7 & 41 \\
\hline & 136 & & & & & & 77 & \\
\hline
\end{tabular}

PAIN

Seventy-nine patients with osteoarthritic changes complained of pain, and the time of onset is shown in Table XXVI. However, Table XXV, which refers to seventy-seven patients, shows that although there was a slight tendency for the anatomically better hips to be less painful, the complaint of pain was fairly uniformly distributed on an anatomical basis. Thus the superior function of the anatomically better hips was due to factors (for example, walking distance) other than the absence of pain. Thirty patients had pain in the absence

vol. 35 B, No. 3 , AUGUST 1953 
of osteoarthritic changes; in sixteen of these the joint was frankly dislocated and seven more showed varying degrees of subluxation. In one case the muscles around a soundly arthrodesed joint were the site of pain.

\begin{tabular}{|c|c|}
\hline \multicolumn{2}{|c|}{$\begin{array}{l}\text { TABI.F XXVI } \\
\text { Osteoarthritic Chaxges AND PAIx } \\
\text { 138 showed radiographic changes but only } \\
\text { seventy-nine of these were affected by pain }\end{array}$} \\
\hline $\begin{array}{c}\text { Age at onset of pain } \\
(79 \text { cases })\end{array}$ & $\begin{array}{l}\text { Number of } \\
\text { patients }\end{array}$ \\
\hline $\begin{array}{l}\text { Before } 20 \text { years } \\
21-30 \text { years } \\
31-40 \text { years } \\
4150 \text { years } \\
\text { (Over } 50 \text { years }\end{array}$ & $\begin{array}{r}15 \\
20 \\
34 \\
5 \\
5\end{array}$ \\
\hline
\end{tabular}

\section{GENERAL DETERIORATION OF THE DISLOCATED HIP}

In an analysis of the results of treatment of a non-lethal condition such as congenital dislocation of the hip, the merits of a long-term review are twofold. The date of review is

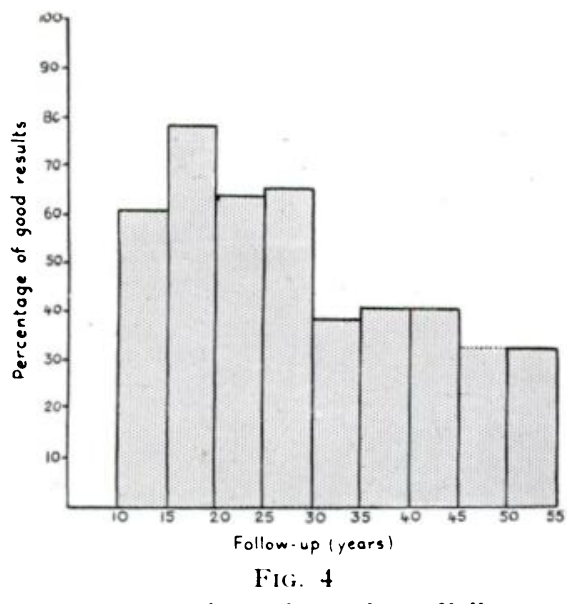

percentage of good results. Follow-up period dates from conclusion of treatment. sufficiently remote from the period of active treatment to ensure that the consequences of whatever has been done are reasonably permanent; in addition, sufficient time will have elapsed to reveal any slow deterioration (or improvement) that must, of necessity, be taken into account in framing a prognosis. It is common knowledge that after the ups and downs of the decade following treatment of a congenitally dislocated hip the general tendency is towards deterioration of the joint. So far this analysis has not been concerned with the durability of the deranged hip. The specific effects of various procedures are known; it is now necessary to determine what, in a general way, may be regarded as the useful "life" of the joint. Figure 4 shows that most hips continue unchanged until the sixth quinquennium of life. Between the ages of, say, twenty-three and thirty-three years nearly half of the satisfactory joints become troublesome in one way or another. However, after that age the survivors continue fairly happily. into middle life.

\section{DISGUSSION AND CONGLUSIONS}

In a series of 889 cases of congenital dislocation of the hip, treated over a fifty-year period corresponding roughly to the first half of the century, it was possible to assess the present state in 264 . The sample is not an accurate one, since it presents features tending to give an unduly favourable picture. Of the cases examined a majority were first seen during the second half of the period, methods of treatment then being better than in the early days when all forms of treatment were still something of a novelty. In these cases, too, there had been less time for the occurrence of the deterioration of the hips which, as is well known, is inevitable. Furthermore, the average age at which patients were first seen was about four and a half years in the sample, whereas it was over seven years in the whole series. Both figure's are a sad exposure of the delay in making the diagnosis which, for too long, has bederilled the treatment of congenital dislocation of the hip in (ireat Britain. 
Nevertheless we believe that the conclusions to be drawn from the examination of the sample are not wholly valueless, and indeed the favourable weighting of the results probably provides a better basis for comparison, in any future investigations, than that of the whole series which would include results dating from the time when the rational treatment of congenital dislocation was only just emerging.

Closed reduction was the method of choice, and such was the antipathy to other methods of treatment that manipulative reduction was attempted in patients well past infancy, and repeated with dogged persistence in cases when the initial attempt had been unsuccessful. Open reduction was usually employed with reluctance, and there was little enthusiasm for secondary corrective procedures such as the shelf operation and rotation osteotomy. Palliative operations such as the Lorenz osteotomy were indispensable in the treatment of a series of cases which included many patients well past the age when satisfactory reduction of the dislocation was possible. This is the general background, against which the following conclusions should be judged.

Closed reduction-There was reason for sober satisfaction with the results of closed reduction. In more than half the cases manipulation and plaster alone were employed. In no less than four-fifths of the unilateral cases so treated before the age of three, and in two-thirds of the bilateral cases the results were satisfactory. Between the ages of three and seven years the unilateral cases still gave almost equally good results, but there was a rapid falling off in the proportion of successes in the bilateral cases.

Immediate open reduction-Nine hips were so treated and the results were only moderate.

Manipulation followed by operation-Secondary operative procedures following manipulative reduction and plaster fixation were employed in twenty-three cases (twenty-six hips) and eleven hips were satisfactory. The shelf operation was the most satisfactory procedure especially when performed within two years from the initiation of treatment. Delayed open reduction would now stand self-condemned, for the decision that closed reduction has failed ought to be made within three months. However, it was formerly supposed that a spurious reduction, in which part of the capsule is caught between the joint surfaces, could ultimately succeed as a result of atrophy by compression of the interposed tissue; and we ourselves, like Severin (1950), have clear evidence from arthrograms that such a phenomenon sometimes occurs.

Closed reduction: late operation-There were patients in whom deterioration occurred some considerable time after closed reduction, the average interval between the initial treatment and the operation designed to relieve the disability being about twelve years. The effectiveness of these interventions, taken as a whole, was not remarkable; the secondary operation gave satisfaction in a little more than one-third of the cases.

No reduction attempted on account of advanced age: late operation-Under half of them were worth the attempt.

No treatment of anykind - There were patients who, in spite of completely neglected dislocations, were able to lead a moderately active life; in about half the cases function was good. The lesson to be learned from this and from the preceding group is that the unreduced dislocation is not a promising lesion for operative attack, at any rate with the procedures that have been described. The nature of the latter is discussed later.

Of the various operations employed some call for comment.

Open reduction-The results were bad; only four out of twenty were satisfactory.

Shelf operation-The shelf operation, on the other hand, gave encouraging results in about two-thirds of the thirty-six hips so treated and, it should be particularly remarked, the operation was effective in some children over the age of five. The notion must be abandoned that this is the upper age limit. As would be expected the best results were in those cases where the remodelling of the roof was anatomically accurate, but even a shelf that was too high was not invariably ineffective.

Vol. 35 B, xo. 3, AUge'st 1953 
Rotation osteotomy-Rotation osteotomies presented a dismal picture; only four out of nine were effective. During the period with which we are concerned, the importance of anteversion as a cause of instability of the reduced hip was either denied or ignored. Re-examination of these cases, as well as the recent experience of one of us (H. J. S.) suggests that this deformity of the femur is, as many other observers have held, by no means negligible. Yet our surgical fathers could retort by pointing out that in these nine hips where an attempt was made to remedy the anteversion the results were hardly such as to justify the effort made.

Abduction, adduction and bifurcation osteotomies - The abduction, adduction and bifurcation osteotomies, a number of them required for the correction of the effects of injudicious treatment, do not inspire confidence. However, there is not enough evidence to warrant condemning them, though sufficient to encourage the search for better alternatives.

The effective life of the successfully treated hip is unquestionably the most important consideration of all. A good result is likely to last until sometime between the twenty-fifth and thirtieth years. Then, during the next decade, there is a rather more than even chance of the joint giving trouble. So far as we know, the survivors continue in fair comfort into middle life.

Osteoarthritis, so-called, occurs in half the cases, but disability was limited to rather more than half of this number.

Pain was a significant complaint in rather more than one-third of all patients re-examined, but sometimes occurred in the absence of a degenerative arthritis.

The significance of the C.E. angle of Wiberg is discussed, and some evidence is provided in favour of taking deliberate steps to improve the shape of a defective acetabular roof.

We are particularly indebted to Mrs Glen Haig, Medical Records Officer, Royal National Orthopaedic llospital, and to her staff, for the great efforts they made to trace errant patients and for their help in the documentation of results. During eleven months of the period of this investigation one of us (G. M. M.) was in receipt of a research grant from the Institute of Orthopaedics.

We were greatly concerned about the statistical significance of the sample of 264 cases. The figures were thoroughly examined by Dr Ian Sutherland of the Department of Statistics, University of London and they have been presented in a form which he approves. For this invaluable aid we are most grateful.

\section{REFERENCES}

Buxtos, St J. D. (1949): Personal communication.

Evans, E. L. (1930): Congenital Dislocation of the Hip. Late Results of Treatment by Manipulation. British Medical Journal, ii, 1,035.

Gill, A. B. (1928): Operation for Old or Irreducible Congenital Dislocation of the Hip. Journal of Bone and Joint Surgery, 10, 696.

Gill, A. B. (1935): Plastic Construction of an Acetabulum. Journal of Bone and Joint Surgery, 17, 48.

Merle D'Aubigné, R. (1952): Reposition with Arthroplasty for Congenital Dislocation of the Hip in Adults. Journal of Bone and Joint Surgery, 34-B, 22.

Royal Commission on Population. Report (1949): London: His Majesty's Stationery Office.

Scaglietti, O. (1932): Studio clinico-statistico sui casi di lussazione congenita dell'anca osservati all' Istituto Ortopedico Rizzoli dal 1899 al 1931. Chirurgia degli Organi di Movimento, 17, 225.

Scaglietri, O. (1939): Resultati della riduzione incruenta e cruenta della lussazione congenita dell'anca. Société internationale de Chirurgie Orthopédique et de Traumatologie, 4e Congrès Berlin 1939. Bruxelles. Seddon, H. J., and Trevor, D.: Unpublished work.

Severin, E. (1941): Contribution to the Knowledge of Congenital Dislocation of the Hip Joint, Late Results of Closed Reduction and Arthrographic Studies of Recent Cases. Acta Chirurgica Scandinavica, 84, Supp. 63. Severin, E. (1950): Congenital Dislocation of the Hip, Development of the Joint after Closed Reduction. Journal of Bone and Joint Surgery, 32-A, 507.

Wiberg, G. (1939): Studies on Dysplastic Acetabula and Congenital Subluxation of the Hip Joint. Acta Chirurgica Scandinavica, 83, Supp. 58. 